\title{
Occurrence of filamentous fungi isolated from matured blue cheese
}

\author{
Ocorrência de fungos filamentosos isolados de queijo azul \\ maturado
}

Eloiza de Souza e Silva Ribeiro', Ariane Flávia do Nascimento, Lorena Dutra Silva², Nathasha de Azevedo Lira², Fabiana Reinis Franca Passamani ${ }^{2}$, Luís Roberto Batista², Filipe Pereira Matteoli ${ }^{*}$ (D)

\author{
${ }^{1}$ Universidade Federal de Alfenas (UNIFENAS), Departamento de Ciência Animal, Alfenas/MG - Brasil \\ ${ }^{2}$ Universidade Federal de Lavras (UFLA), Departamento de Ciência dos Alimentos, Lavras/MG - Brasil \\ ${ }^{3}$ Universidade Federal de Santa Catarina (UFSC), Departamento de Microbiologia, Imunologia e Parasitologia, \\ Florianópolis/SC - Brasil
}

${ }^{*}$ Corresponding Author: Filipe Pereira Matteoli, Universidade Federal de Santa Catarina (UFSC), Departamento de Microbiologia, Imunologia e Parasitologia, Rua Engenheiro Agronômico Andrei Cristian Ferreira, s/n, Trindade, CEP: 88040-900, Florianópolis/SC - Brasil, e-mail: matteolifilipe@gmail.com

Cite as: Ribeiro, E. S. S., Nascimento, A. F., Silva, L. D., Lira, N. A., Passamani, F. R. F., Batista, L. R., \& Matteoli, F. P. (2020). Occurrence of filamentous fungi isolated from matured blue cheese. Brazilian Journal of Food Technology, 23, e2019074. https://doi.org/10.1590/1981-6723.07419

\begin{abstract}
Matured blue cheese can be made from cow's milk associated with the inoculated fungus Penicillium roqueforti, which guarantees specific sensorial characteristics. Recently, Brazil's fine cheese production and consumption have increased by more than $200 \%$, highlighting the relevance of microbiological quality control of these products. Fungal contaminations are responsible for significant losses in cheese production and provide a suitable environment for mycotoxins production, constituting a hazard to public health. In this work, we evaluated the mycological contamination profile of matured blue cheeses commercialized in Brazil. Samples of ten different brands were analyzed by serial dilution method, by plating in the Dicloran Rose of Bengal Chloramphenicol (DRBC) culture medium and Dicloran Glycerol Medium Base (DG18). Subsequently, different fungi morphotypes were isolated and morphologically identified. As a result, 461 fungi were isolated and identified, notably Aspergillus aculeatus, Penicillium roqueforti and Penicillium solitum. All samples were contaminated by filamentous fungi, amongst those, many already reported as mycotoxin producers, which underlines the relevance of microbiological monitoring.
\end{abstract}

Keywords: Aspergillus; Dairy; Food microbiology; Mycology; Food safety; Morphological characterization.

\section{Resumo}

O queijo azul maturado pode ser fabricado a partir do leite de vaca, associado à inoculação do fungo Penicillium roqueforti, o qual confere características sensoriais específicas. Recentemente, a produção e o consumo de queijos finos no Brasil aumentaram mais de $200 \%$, destacando a relevância do controle de qualidade microbiológica desses produtos. Contaminações fúngicas são responsáveis por perdas significativas na produção de queijos e provêm um ambiente propício para a produção de micotoxinas, constituindo-se um risco à saúde pública. Neste trabalho, avaliamos o perfil de contaminação micológica de queijos azuis maturados comercializados no Brasil. Amostras de 
dez diferentes marcas foram analisadas pelo método de diluição seriada, através de plaqueamento em meio de cultura Ágar Dicloran Rosa de Bengala Cloranfenicol (DRBC) e Ágar Dicloran Glicerol Médium Base (DG18). Subsequentemente, diferentes morfotipos fúngicos foram isolados e morfologicamente identificados. Como resultados, 461 fungos foram isolados e identificados, notavelmente, Aspergillus aculeatus, Penicillium roqueforti e Penicillium solitum. Todas as amostras analisadas apresentaram contaminação por fungos filamentosos, muitos dos quais já reportados como produtores de micotoxinas, enfatizando a relevância do monitoramento microbiológico.

Palavras-chave: Aspergillus; Laticínios; Microbiologia de alimentos; Micologia; Segurança de alimentos; Caracterização morfológica.

\section{Introduction}

Blue cheese is characterized by its moldy flavor and blue-green veined appearance, created by maturation process and Penicillium roqueforti growth that produces lytic enzymes such as lipases and decarboxylases (Cantor et al., 2017). These enzymes can convert the fatty acids via $\beta$-oxidative pathways, increasing the presence of methyl-ketones, mostly 2-pentanone, 2-heptanone and 2-nonanone, directly involved in blue cheese sensory characteristics (Cao et al., 2014). Gorgonzola is produced from pasteurized cow milk, and is one of the most consumed blue-veined cheeses. Since 1996, Gorgonzola manufacturers awarded a European protected designation of origin (European Union, 1996). In Brazil, it is established that blue cheese needs to be ripened for 35 days (Brasil, 2007), if the maturation is performed at least for 90 days, this matured blue cheese (MBC) can be commercialized as Roquefort type or Gorgonzola type, being the latter produced exclusively from cow milk (Brasil, 1952).

Although pasteurization is an efficient method for milk microbiological control (Van Asselt et al., 2017), undesirable contaminations may occur during manufacturing procedures, namely introduction of starter culture, ripening or brining (Banjara et al., 2015). Brine salting is a crucial step of MBC manufacture, which conveys characteristics $\mathrm{NaCl}$ gradient from surface to the core, meanwhile halotolerant microorganisms are also selected for further ripening (Martín \& Coton, 2016).

$P$. roqueforti proteolytic activity increases the $\mathrm{pH}$, creating a suitable environment for fungal growth and development in long ripening cheeses (Bernini et al., 2015; Mucchetti \& Neviani, 2006). Among the commonly isolated cheese-associated fungi, the genera Penicillium, Aspergillus, Cladosporium cladosporioides complex, Geotrichum, Mucor and Trichoderma are the most frequently described (Hymery et al., 2014).

However, not all the isolated fungi species exert beneficial effects; some mold growth may produce secondary metabolites, known as mycotoxins, hence constituting a potential risk to public health (Chen et al., 2010). Cheese properties and safety are directly related to the microbial community in the product; therefore, many studies have been conducted to assess commonly associated bacteria, yeast and fungal species (Dugat-Bony et al., 2016; Dobson, 2017; Ramos-Pereira et al., 2019). Nonetheless, in Brazil, one of the world's largest dairy producer, mycological contamination data regarding milk-based products are still scarce (Lemos et al., 2018). Therefore, this work assesses the mycological profile in ten different brands of MBCs commercialized throughout Brazil.

\section{Material and methods}

This study was conducted in the Food Mycology and Mycotoxins Laboratory - Department of Food Science, at Federal University of Lavras - UFLA, city of Lavras, Minas Gerais, Brazil. Ten samples, each from a different brand, of MBCs were obtained from stores in Southern Minas Gerais (21 $14^{\prime} 43^{\prime \prime} \mathrm{S}$, $44^{\circ} 59^{\prime} 59^{\prime \prime} \mathrm{W}$ ). All samples were produced in dairy factories under federal inspection and are allowed to be traded across the country. After purchase, these samples were stored under refrigeration $\left(4^{\circ} \mathrm{C}\right)$. 
Samples were analyzed using the serial dilution method, to obtain the first dilution; $25.0 \mathrm{~g}$ of each MBCs were diluted in $225 \mathrm{~mL}$ of peptone water $0.1 \%$. Next, this solution was macerated and kept under agitation in Stomacher ${ }^{\circledR}$ (Metroterm, Brazil), using a paddle speed of 490/min for 2 minutes. Then, sample aliquots of $0.1 \mathrm{~mL}(1: 10,1: 100,1: 1000$ and 1:10000) were spread on petri plates surfaces containing Dichloran Rose-Bengal Chloramphenicol Agar (DRBC) and Dichloran Glycerol Medium Base (DG18) (Merck Millipore, United States) media, according to the spread plate technique. DRBC and DG18 media were prepared according to Hocking \& Pitt (1980). Plates were incubated in BOD, at $25^{\circ} \mathrm{C}$, from 5 to 7 days, for posterior filamentous fungi analysis. Each sample of the study was run in triplicate.

After colony growth in plates, colony forming units (CFUs) were counted as described in other study (Pitt \& Hocking, 1997). Colonies were individually characterized by size, conidia color, mycelium and reverse color, and then they were grouped into morphotypes. A representative sample of each sample was obtained through the square root method (Sengun et al., 2009) accounting to the total number of counted isolates $(n=461)$. Subsequently, fungi colonies were selected and transferred to petri plates containing Malt Extract Agar (MEA) medium (Merck Millipore, United States) and incubated in BOD at $25{ }^{\circ} \mathrm{C}$, during seven days.

Pure colonies were transferred to identification media, according to each genus. Isolates of Aspergillus and Penicillium genera were grown in petri plates containing Czapek Yeast Agar (CYA) (Merck Millipore ${ }^{\circledR}$ ) medium, at $25^{\circ} \mathrm{C}$ and $37^{\circ} \mathrm{C}$, and MEA medium at $25^{\circ} \mathrm{C}$ (Klich, 2002), while other genera were grown in MEA only at $25^{\circ} \mathrm{C}$. After seven days of incubation, the macroscopic and microscopic characteristics of the filamentous fungi were observed, to discriminate morphological hallmarks (Samson et al., 2014; Visagie et al., 2014).

Observed macroscopic features were colony color, mycelial characteristics, presence or absence of exudate, reverse color, colony diameter, presence or absence of soluble pigmentation and sclerotia/cleistothecia morphology. The microscopic properties evaluated were branch types, conidiophores length, texture and width, metulae and phialides length and texture, conidia form and texture. These structures were observed through optical microscope (Bioval, Brasil). Fully characterized isolates were stored in microtubes, and integrated into the culture collection of the Food Mycology and Mycotoxins Laboratory - Department of Food Science, Federal University of Lavras - UFLA, Lavras - MG.

\section{Results and discussion}

We were able to retrieve filamentous fungi from all ten samples, accounting a total of 461 isolates. One sample (2) presented the highest level of retrieved fungi isolates (106) or $23 \%$ of total, while samples 7 and 10 presented the fewest fungal presence (14 and 15) isolates or $3.03 \%$ and $3.35 \%$ respectively (Figure 1).

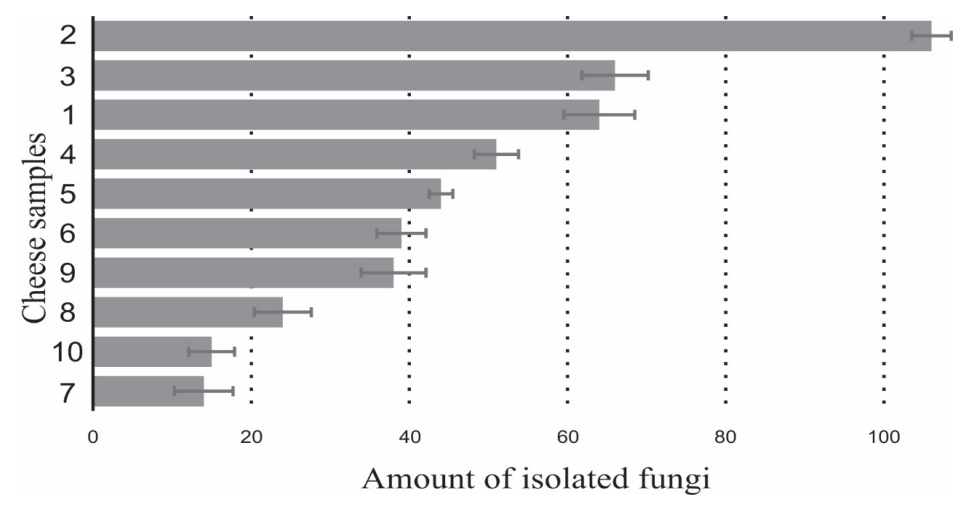

Figure 1. Total amount of fungi isolates found in ten different samples of Brazilian matured blue cheese. 
In MBCs, it is expected to found mainly P. roqueforti or common cheese-associated fungi (Seratlić et al., 2011). In fact, the vast majority of fungi obtained in this work were classified as $P$. roqueforti $(\mathrm{n}=282)$. Other fungi species were also obtained and classified into two main groups, the common cheese-associated and possible contaminants (Non $P$. roqueforti).

Figure 2 shows the distribution of non $P$. roqueforti isolates $(\mathrm{n}=179)$ across samples. Most samples with high amount of fungi isolates (Figure 1), also contributed mainly to the total amount of non-P. roqueforti found. However, sample 1 data highlights the relevance of complete morphological characterization, since most of this sample's amount of isolated fungi (Figure 1) do not belong to any other species rather than $P$. roqueforti (Figure 2 ).

Cheese-associated fungi isolates are those species already reported as players in cheese ripening microbiota such as: $P$. brevicompactum, $P$. commune, $P$. verrucosum, $A$. versicolor, and Geotrichum candidum (Martín \& Coton, 2016). Whilst contaminants fungi are introduced mainly through animal feed or the environment (Hymery et al., 2014). Non-P. roqueforti species are a concern in matured cheeses as it can be an indication of mycotoxin producers, such as Aspergillus spp. (Ozturkoglu-Budak \& De Vries, 2017).

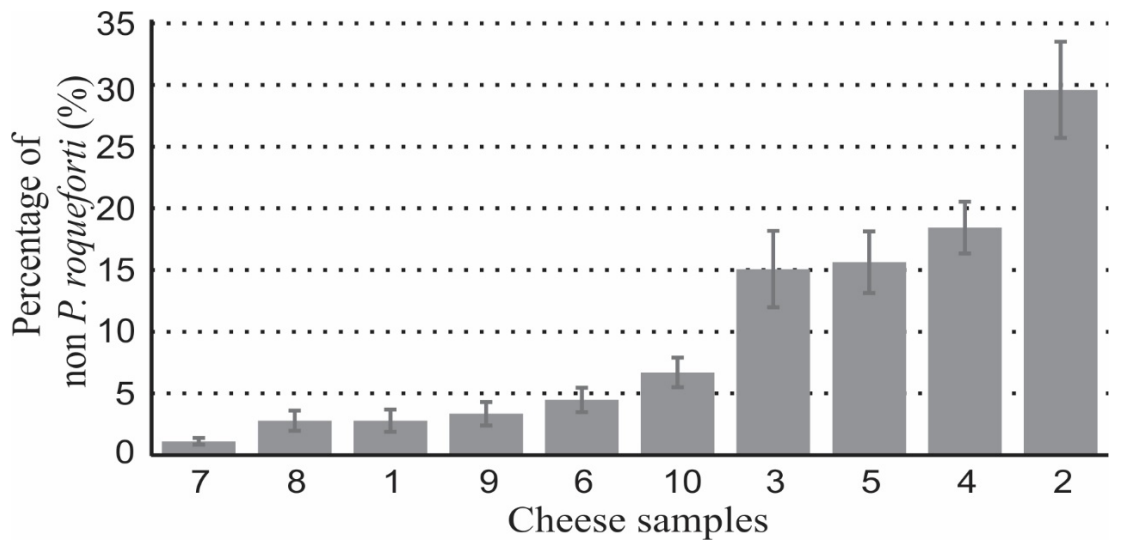

Figure 2. Percentage of non-P. roqueforti isolates $(n=179)$ in ten different samples of Brazilian matured blue cheese.

Assuming that the pasteurization process was properly conducted, the majority of milk contaminants should have been previously removed or inactivated (Heiman et al., 2016), indicating that contamination may also occur either from starter strains, environment, processing equipment or even from incorrect manipulation. Although filamentous fungi grow very slowly, their growth can produce hazardous secondary metabolites known as mycotoxins, constituting risk to consumers, especially in long-ripening milk products as MBCs. Thus, we assessed all non-P. roqueforti species to address their taxonomic filiation.

We have found several species belonging to both Aspergillus and Penicillium genera. The majority of isolates belong to A. aculeatus (30.72\%) and P. solitum (21.79\%) species (Figure 3). Unexpectedly, Geotrichum candidum was the third most prevalent species (16.2\%). 


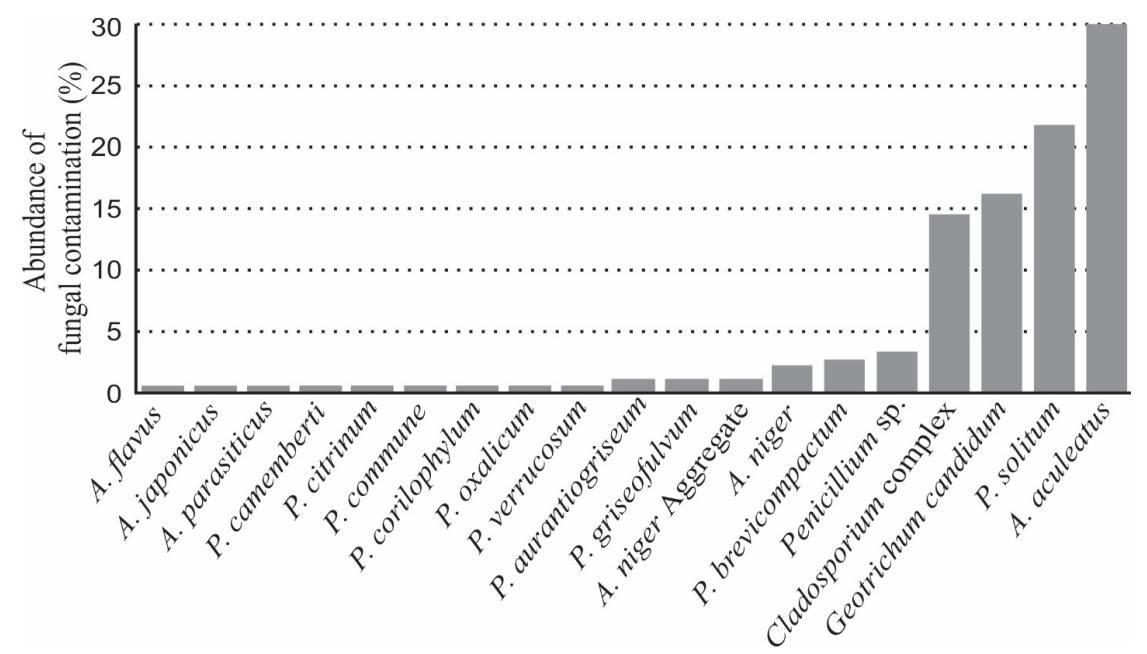

Figure 3. Taxonomic affiliation of isolated fungi in ten different samples of Brazilian matured blue cheese.

In addition, G. candidum and Cladosporium sp. were already characterized as commonly associated to mold-ripened cheeses microbiota. Thus, these isolates should not be considered exogenous contaminants. The genera Penicillium, Aspergillus and Cladosporium, have been documented in other studies that showed strong presence along cheese production chain (Ozturkoglu-Budak \& De Vries, 2017).

Geotrichum candidum is a common milk-associated dimorphic yeast. It has been shown that this microorganism can contribute positively in taste and aroma of dairy products, further $G$. candidum growth can exert antagonistic effect on undesirable microorganisms such as Mucor spp. and Listeria monocytogenes (Alper et al., 2011). A recent whole genome sequencing study compared G. candidum and other Saccharomycotina yeasts and bring to light the differential gene content of this yeast, which may explain its biochemical properties (Morel et al., 2015). For instance, this dairy yeast has four carboxylesterase/type B lipase genes with no clear homologs in Saccharomycotina, but equivalents in Pezizomycotina, these lipases are secreted extracellular enzymes, and can play a key role in cheese aroma formation through triacylglycerol metabolism.

One of the most prevalent fungi reported here is Cladosporidium spp., this fungus is an air-carried fungus, and it generally comes from the ventilation system or dust, being commonly found in cheese (Nevalainen et al., 2015). This fungus presence can cause black tight spots on cheese's surface, deteriorating the aesthetical, nutritional and organoleptic properties of the cheese (Messini et al., 2017).

We also characterized many other species of Penicillium genus such as: $P$. solitum, $P$. verrucosum, $P$. brevicompactum, $P$. commune which, amongst others, have already been documented as commonly associated to mold-ripened cheese (Desmasures, 2014) however, their clear role in cheese-ripening is still unclear. Another cheese mycological survey performed in Spain found the same general profile described here, assessing C. sphaerospermum, G. candidum and P. solitum as the most prevalent species in ovine raw milk cheese (Manchego) (Marín et al., 2015). Interestingly, Marín and colleagues further reported several Fusarium spp. occurrences, indicating that pasteurization increases food safety of Gorgonzola type cheese.

Furthermore, we characterized $P$. camemberti, which is widely used in fine cheese manufacturing like camembert and brie cheeses (Hymery et al., 2014), and can be encountered mainly due to its introduction during cheese making. Meanwhile, other species (A. aculeatus, A. flavus, A. japonicus, A. niger, A. parasiticus, $P$. aurantiogriseum and $P$. citrinum, $P$.corylophilum) are unexpected in ripened cheeses, and probably constitute environmental contamination (Dobson, 2017).

Overall, matured blue cheese is a complex food ecosystem with variable gradients of $\mathrm{pH}$ and $\mathrm{NaCl}$, but low levels of $\mathrm{O}_{2}$ and $\mathrm{CO}_{2}$. This heterogeneity creates different habitats on the surface and in the core of the 
cheese, which select specific micropopulations (Cantor et al., 2017). Disturbances in this regular distribution are mainly associated to contamination during salting stage, or due to air flow.

One of highest concerns regarding fungal contamination are the mycotoxins, these low-molecular weight molecules are secondary metabolites, hence are not directly essential for fungal growth (Hymery et al., 2014). Despite its relevance, no clear function has been established for secondary metabolites yet. Some authors claim that these molecules are related to niche competition (Fox \& Howlett, 2008). Mycotoxins can be harmful to humans causing mycotoxicosis, ranging from simple food poisoning to carcinogenic effects, depending on the type of mycotoxins, concentration and exposure rate (Rocha et al., 2014). On top of the list, mycotoxins are known for their industrial processing resistance; since mold can grow on a wide range of foods at any stage of production, food fungi surveillance is a relevant practice to ensure consumers health.

The main mycotoxins reported in cheese are roquefortine $\mathrm{C}$, patulin, cyclopiazonic acid, mycophenolic acid, citrinin, aflatoxin, ochratoxin A amongst others (Dobson, 2017). Here we also report the presence of notorious mycotoxin producing fungi, namely: A. flavus, A. japonicus, A. parasiticus, A. niger, P. verrucosum and $P$. citrinum. Even though morphological characterization by itself is not suitable to detect mycotoxin production, it still constitutes a reliable tool to perform overall mycological profile and can be extended by enzymatic detection assays. Aflatoxin M1 is the only mycotoxin controlled by the Brazilian Health Regulatory Agency (ANVISA) in cheese, a maximum tolerable limit is $2.5 \mu \mathrm{g} / \mathrm{kg}$ (Brasil, 2011),

Aspergilli species reported in this work belong mainly to Nigri section, known as black aspergilli, A. aculeatus is also a member of Nigri section and was by far the most prevalent species characterized in all analyzed samples (Figure 3). This group is responsible for producing a variety of bioactive natural products, including aculeacins (antibiotics and antifungal agents), CJ-15,183 (antifungal agent) and secalonic acids (toxins) (Yodsing et al., 2018). Although no clear risk of A. aculeatus presence in cheese has been assessed yet, this species wields an array of molecular weapons against other microorganisms, and could impair proper $P$. roqueforti development affecting the final quality of blue veined cheese.

Our results show that $P$. roqueforti and cheese-associated fungi species presented the highest prevalence in all analyzed samples, which corroborates the current data (Martín \& Coton, 2016) and other microbiological surveillance data in blue cheese (Banjara et al., 2015). We also reported the presence of other aspergilli species, which may be caused by environmental contamination, with a higher prevalence of A. aculeatus, emphasizing the relevance of mycological monitoring of matured blue cheese for both industry and consumers.

\section{Conclusion}

1. There was no direct correlation between total amount of isolated fungi and contaminants, thus morphological characterization is necessary to assess contaminated samples;

2. A. aculeatus was the most prevalent exogenous species in the analyzed samples, this fungus massive presence can indicate that $P$. roqueforti growth was impaired, compromising the quality of the products;

3. Mycotoxin producing species have been characterized, however mycotoxin presence was not assessed.

\section{Acknowledgements}

This study was funded by CAPES, FAPEMIG and CNPq.

\section{References}

Alper, I., Frenette, M., \& Labrie, S. (2011). Ribosomal DNA polymorphisms in the yeast Geotrichum candidum. Fungal Biology, 115(12), 1259-1269. PMid:22115445. http://dx.doi.org/10.1016/j.funbio.2011.09.002

Banjara, N., Suhr, M. J., \& Hallen-Adams, H. E. (2015). Diversity of yeast and mold species from a variety of cheese types. Current Microbiology, 70(6), 792-800. PMid:25694357. http://dx.doi.org/10.1007/s00284-015-0790-1 
Bernini, V., Dalzini, E., Lazzi, C., Bottari, B., Bisotti, S., Fontana, M., \& Neviani, E. (2015). A multi-sampling approach to evaluate an infrared surface treatment for reducing Listeria monocytogenes contamination on whole Gorgonzola cheese rinds. Food Control, 55, 75-81. http://dx.doi.org/10.1016/j.foodcont.2015.02.032

Brasil. (1952, março 29). Aprova o novo regulamento da inspeção industrial e sanitária de produtos de origem animal (Decreto n 30.691, de 29 de março de 1952). Diário Oficial da União, Brasília.

Brasil. (2007, outubro 23). Adota o regulamento técnico de identidade e qualidade de queijo azul, na forma do anexo à presente instrução normativa (Instrução Normativa n 45, de 23 de outubro de 2007). Diário Oficial da União, Brasília.

Brasil. Ministério da Saúde. Agência Nacional de Vigilância Sanitária - ANVISA. (2011, fevereiro 22). Dispõe sobre limites máximos tolerados (LMT) para micotoxinas em alimentos (Resolução $n^{\circ} 7$, de 18 de fevereiro de 2011). Diário Oficial da União, Brasilia.

Cantor, M. D., Van Den Tempel, T., Hansen, T. K., \& Ardö, Y. (2017). Blue cheese. In P. McSweeney, P. Fox, P. Cotter \& D. Everett (Eds.), Cheese (4th ed., Chap. 37, pp. 929-954). Amsterdam: Elsevier. http://dx.doi.org/10.1016/B978-0-12-4170124.00037-5.

Cao, M., Fonseca, L. M., Schoenfuss, T. C., \& Rankin, S. A. (2014). Homogenization and lipase treatment of milk and resulting methyl ketone generation in blue cheese. Journal of Agricultural and Food Chemistry, 62(25), 5726-5733. PMid:24460517. http://dx.doi.org/10.1021/jf4048786

Chen, L. S., Ma, Y., Maubois, J. L., Chen, L. J., Liu, Q. H., \& Guo, J. P. (2010). Identifcation of yeasts from raw milk and selection for some specific antioxidant properties. International Journal of Dairy Technology, 63(1), 47-54.

http://dx.doi.org/10.1111/j.1471-0307.2009.00548.x

Desmasures, N. (2014). Mold-ripened varieties. In C. A. Batt (Ed.), Encyclopedia of food microbiology (2nd ed., Vol. 2, pp. 409416). London: Academic Press.

Dobson, A. D. (2017). Mycotoxins in cheese. In P. McSweeney, P. Fox, P. Cotter \& D. Everett (Eds.), Cheese (4th ed., Chap. 23, pp. 595-601). Amsterdam: Elsevier. http://dx.doi.org/10.1016/B978-0-12-417012-4.00023-5.

Dugat-Bony, E., Garnier, L., Denonfoux, J., Ferreira, S., Sarthou, A. S., Bonnarme, P., \& Irlinger, F. (2016). Highlighting the microbial diversity of 12 French cheese varieties. International Journal of Food Microbiology, 238, 265-273. PMid:27710867. http://dx.doi.org/10.1016/j.jifoodmicro.2016.09.026

European Union. (1996). Commission Regulation (EC) No 1107/96 of 12 June 1996. On the registration of geographical indications and designations of origin under the procedure laid down in Article 17 of Council Regulation (EEC) No 2081/92, L148. Official Journal of the European Communities (Vol. 148, No. 21/06), Brussels.

Fox, E. M., \& Howlett, B. J. (2008). Secondary metabolism: Regulation and role in fungal biology. Current Opinion in Microbiology, 11(6), 481-487. PMid:18973828. http://dx.doi.org/10.1016/j.mib.2008.10.007

Heiman, K., Garalde, V., Gronostaj, M., Jackson, K., Beam, S., Joseph, L., Saupe, A., Ricotta, E., Waechter, H., Wellman, A., Adams-Cameron, M., Ray, G., Fields, A., Chen, Y., Datta, A., Burall, L., Sabol, A., Kucerova, Z., Trees, E., Metz, M., Leblanc, P., Lance, S., Griffin, P. M., Tauxe, R. V., \& Silk, B. J. (2016). Multistate outbreak of listeriosis caused by imported cheese and evidence of cross-contamination of other cheeses, USA, 2012. Epidemiology and Infection, 144(13), 2698-2708. PMid:26122394. http://dx.doi.org/10.1017/S095026881500117X

Hocking, A. D., \& Pitt, J. I. (1980). Dichloran-glycerol medium for enumeration of xerophilic fungi from low-moisture foods. Applied and Environmental Microbiology, 39(3), 488-492. PMid:7387151. http://dx.doi.org/10.1128/AEM.39.3.488-492.1980

Hymery, N., Vasseur, V., Coton, M., Mounier, J., Jany, J. L., Barbier, G., \& Coton, E. (2014). Filamentous fungi and mycotoxins in cheese: A review. Comprehensive Reviews in Food Science and Food Safety, 13(4), 437-456. http://dx.doi.org/10.1111/15414337.12069

Klich, M. A. (2002). Identification of common Aspergillus species. Utrechtn: Centraalbureau voor Schimmelcultures.

Lemos, J. G., Garcia, M. V., Mello, R. O., \& Copetti, M. V. (2018). Consumers complaints about moldy foods in a Brazilian website. Food Control, 92, 380-385. http://dx.doi.org/10.1016/j.foodcont.2018.05.017

Marín, P., Palmero, D., \& Jurado, M. (2015). Occurrence of moulds associated with ovine raw milk and cheeses of the Spanish region of Castilla La Mancha. International Journal of Dairy Technology, 68(4), 565-572. http://dx.doi.org/10.1111/14710307.12208

Martín, J. F., \& Coton, M. (2016). Blue cheese: Microbiota and fungal metabolites. In J. Frias, C. Martinez-Villaluenga \& E. Peñas (Eds.), Fermented foods in health and disease prevention (Chap. 12, pp. 275-303). Amsterdam: Elsevier.

Messini, A., Buccioni, A., Minieri, S., Mannelli, F., Mugnai, L., Comparini, C., Venturi, M., Viti, C., Pezzati, A., \& Rapaccini, S. (2017). Effect of chestnut tannin extract (Castanea sativa Miller) on the proliferation of Cladosporium cladosporioides on sheep cheese rind during the ripening. International Dairy Journal, 66, 6-12. http://dx.doi.org/10.1016/j.idairyj.2016.10.012

Morel, G., Sterck, L., Swennen, D., Marcet-Houben, M., Onesime, D., Levasseur, A., Jacques, N., Mallet, S., Couloux, A., Labadie, K., Amselem, J., Beckerich, J. M., Henrissat, B., Van de Peer, Y., Wincker, P., Souciet, J. L., Gabaldón, T., Tinsley, C. R., \& Casaregola, S. (2015). Differential gene retention as an evolutionary mechanism to generate biodiversity and adaptation in yeasts. Scientific Reports, 5(1), 11571. PMid:26108467. http://dx.doi.org/10.1038/srep11571

Mucchetti, G., \& Neviani, E. (2006). Microbiologia e tecnologia lattiero-casearia. Milan: Tecniche Nuove.

Nevalainen, A., Täubel, M., \& Hyvärinen, A. (2015). Indoor fungi: Companions and contaminants. Indoor Air, 25(2), 125-156. PMid:25601374. http://dx.doi.org/10.1111/ina.12182 
Ozturkoglu-Budak, S., \& De Vries, R. P. (2017). Mold-ripened and raw milk cheeses: Production, risks, and benefits to human health. In R. R. Watson, R. J. Collier \& V. R. Preedy (Eds.), Dairy in human health and disease across the lifespan (pp. 353361). Amsterdam: Elsevier. http://dx.doi.org/10.1016/B978-0-12-809868-4.00027-3.

Pitt, J. I., \& Hocking, A. D. (1997). Fungi and food spoilage. London: Blackie Academic and Professional.

Ramos-Pereira, J., Mareze, J., Patrinou, E., Santos, J. A., \& López-Díaz, T. M. (2019). Polyphasic identification of Penicillium spp. isolated from Spanish semi-hard ripened cheeses. Food Microbiology, 84, 103253. PMid:31421787. http://dx.doi.org/10.1016/j.fm.2019.103253

Rocha, M. E. B., Freire, F. D. C. O., Maia, F. E. F., Guedes, M. I. F., \& Rondina, D. (2014). Mycotoxins and their effects on human and animal health. Food Control, 36(1), 159-165. http://dx.doi.org/10.1016/j.foodcont.2013.08.021

Samson, R. A., Visagie, C. M., Houbraken, J., Hong, S. B., Hubka, V., Klaassen, C. H., Perrone, G., Seifert, K. A., Susca, A., Tanney, J. B., Varga, J., Kocsube, S., Szigeti, G., Yaguchi, T., \& Frisvad, J. C. (2014). Phylogeny, identification and nomenclature of the genus Aspergillus. Studies in Mycology, 78, 141-173. PMid:25492982. http://dx.doi.org/10.1016/j.simyco.2014.07.004

Sengun, I. Y., Nielsen, D. S., Karapinar, M., \& Jakobsen, M. (2009). Identification of lactic acid bacteria isolated from Tarhana, a traditional Turkish fermented food. International Journal of Food Microbiology, 135(2), 105-111. PMid:19703719. http://dx.doi.org/10.1016/j.ijfoodmicro.2009.07.033

Seratlić, S. V., Miloradović, Z. N., Radulović, Z. T., \& Maćej, O. D. (2011). The effect of two types of mould inoculants on the microbiological composition, physicochemical properties and protein hydrolysis in two Gorgonzola-type cheese varieties during ripening. International Journal of Dairy Technology, 64(3), 408-416. http://dx.doi.org/10.1111/j.1471-0307.2011.00692.x

Van Asselt, E., Van Der Fels-Klerx, H., Marvin, H., Van Bokhorst-Van De Veen, H., \& Groot, M. N. (2017). Overview of food safety hazards in the European dairy supply chain. Comprehensive Reviews in Food Science and Food Safety, 16(1), 59-75. http://dx.doi.org/10.1111/1541-4337.12245

Visagie, C. M., Houbraken, J., Frisvad, J. C., Hong, S. B., Klaassen, C. H., Perrone, G., Seifert, K. A., Varga, J., Yaguchi, T., \& Samson, R. A. (2014). Identification and nomenclature of the genus Penicillium. Studies in Mycology, 78, 343-371. PMid:25505353. http://dx.doi.org/10.1016/j.simyco.2014.09.001

Yodsing, N., Lekphrom, R., Sangsopha, W., Aimi, T., \& Boonlue, S. (2018). Secondary metabolites and their biological activity from Aspergillus aculeatus KKU-CT2. Current Microbiology, 75(5), 1-6. PMid:29248948. http://dx.doi.org/10.1007/s00284-017$1411-y$

Funding: Ministério da Ciência, Tecnologia e Inovação/Conselho Nacional de Desenvolvimento Científico e Tecnológico (CNPq); Coordenação de Aperfeiçoamento de Pessoal de Nível Superior (CAPES); Fundação de Amparo à Pesquisa do Estado de Minas Gerais (FAPEMIG). 